\title{
A Study of Dakwah Pattern on Dramatic Text and Its Transformation From Serat Menak Lare Literature to the Choreography Text of Srimpi Dance
}

\author{
R.M. Pramutomo ${ }^{1 *}$, Sri Rochana Widyastutieningrum ${ }^{2}$ and Jonet Sri Kuncoro ${ }^{3}$ \\ 1 Institut Seni Indonesia (ISI) Surakarta, Indonesia; rmpram60@gmail.com \\ 2 Institut Seni Indonesia (ISI) Surakarta, Indonesia; sri.rochana.w@gmail.com \\ 2 Institut Seni Indonesia (ISI) Surakarta, Indonesia; jonetsrikuncoro@yahoo.co.id \\ * Correspondence
}

Received: 2020-03-21; Accepted: 2020-04-04; Published: 2020-06-25

\begin{abstract}
The Srimpi dance is a Javanese dance which is presented by four female dancers. Usually, the Srimpi dancers are four female teenagers. The dance itself is based on literature. On the Srimpi Menak lare variation, the dance is performed by four child dancers, specifically by two boys and two girls. The Srimpi Menak Lare dance was inspired from the childhood tale of Tiyang Agung Jayengrana or Amir Ambyah, one of the uncles of Prophet Muhammad on a play by R.Ng. Yosodipuro I. The dramatical transformation in said play, when choreographically visualized, becomes a topic of discussion. This article will examines a study of dance elements which is pattered by da'wah in Islamic point of view. Based on said discussion, the creation of Srimpi Menak Lare dance is a research-based dance creation from the idea forming, exploration, concept building, and the forming of the dance itself. The methodological application in this artistic research refers to the analitycal form of the innovative choreography of the Srimpi Menak Lare dance. Through this specific term of da'wah pattern this article applied an exploration of elements of dance creation related to the contens of da'wah in Islamic values.
\end{abstract}

Keywords: Srimpi dance; concept of choreography; dance forming.

Abstract: Karya tari Srimpi adalah genre atau jenis penyajian tari Jawa yang ditarikan oleh empat orang penari perempuan. Pada umumnya genre tari Srimpi ditarikan oleh penari putri yang berusia remaja. Pada Penciptaan Tari Srimpi dapat bersumber dari cerita dari karya sastra. Pada karya Srimpi Menak Lare tarian ini ditarikan oleh empat orang penari, namun dibawakan oleh 2 peraga tari lakilaki dan 2 peraga tari perempuan yang masih usia anak-anak. Inspirasi gagasan ini mendorong penciptaan Tari Srimpi Menak Lare yang bertutur tentang masa kanak-kanak dan keteladanan Tiyang Agung Jayengrana atau Amir Ambyah yang juga dikenal sebagai Paman Nabi Muhammad dalam sastra lakon karya R.Ng. Yosodipuro I. Transformasi dramatik dalam sastra lakon menjadi topic kajian ketika divisualkan secara koreografis. Artikel ini berupaya mengkaji elemen-elemen kreasi tari yang dipolakan sebagai da'wah menurut sudut pandang Islam.Atas dasar itu penciptaan Tari Srimpi Menak Lare adalah penciptaan tari berbasis riset dengan metode penuangan sejak dari tahap penuangan gagasan, eksplorasi, pembangunan konsep, dan perwujudan bentuk tari. Aplikasi metodologis dalam penelitian artistik ini mengarah pada bentuk analisis koreografi inovatif Tari Srimpi Menak Lare. Melalui artikel ini secara specific pola da'wah dipandang sebagai istilah untuk diaplikasikan sebagai elemen bentuk kreasi tari khususnya berkaitan dengan da'wah sebagai unsure nilai Islami.

Keywords: Tari Srimpi; Bentuk Tari; Konsep Koreografi. 


\section{Introduction}

The creation of the Srimpi Menak Lare dance is based of the Menak Lare play, created by R.Ng. Yosodipura I titled Serat Menak Lare. The play depicts the innocent and pure imagination of the life of children. The main character of the Menak Lare play is Tiyang Agung Menak Jayengrana, better known as Amir Ambyah. This character inspires diligence, which is then developed as a material of Srimpi Menak Lare's dramatization (I. 1981).

The Srimpi Menak Lare dance is a visualization of a dance form that depicts the diligence of its main character, Amir Ambyah or Tiyang Agung Menak Jayengrana. In the play's tradition, this character is an uncle of Prophet Muhammad, which supports the local wisdom and moral teachings. Another contribution of the Srimpi Menak Lare dance also promotes innovative aspects in the visualization of its movements.

In addition, its artistic educational aspect can be observed from its teenage performers that consist of two boys and two girls. This will produce a technical pattern, interpretive pattern, and aesthetical pattern as its contribution.

This age range was chosen because in the Surakarta-style Javanese dance tradition, a Bedhaya Endhol-endhol dance genre was gifted by Susuhunan Paku Buwana X to Sri Paku Alam VIII in Yogyakarta. In addition, the Yogyakarta-style tradition has the Srimpi Renggawati tradition which main character, Dewi Renggawati, was played by a prepubescent girl. This inspiration supports the creation of Srimpi Menak Lare dance which depicts the childhood and diligence of Tiyang Agung Jayengrana or Amir Ambyah, also know as the uncle of Prophet Muhammad in the play created by R.Ng. Yosodipuro I (Astarinny \& Pramutomo, 2020).

Another reason for the use of child performers is that a child's character development is faster, because they are still innocent and unburdened by other rational suspiciousness, which makes the Srimpi Menak Lare dance able to represent the choreography pattern of a child. This shows how to molding process in the creation of the Srimpi Menak Lare dance is applied in the art creation process. The molding process of the Srimpi Menak Lare dance is also used in the artistic research method.

In particular, several other studies were also reviewed to prove that this article has a different study position. A study of the da'wah pattern article was written by Qomariah Moehson in the title 'Da'wah Humanists Through the Movement of the Congregation' in DAWAH ILMU Journal Volume 39 Number 2 of 2019 (Moehson; 2019: 183-196). The discussion presented focuses on the importance of the humanist side in determining the da'wah pattern strategy.

Something similar is found in articles written by Etti Khusnul Khotiman and Alief Budiyono "Reducing Stress Levels in the Purbalingga Street Art Community through Graffiti and Murals" published in the same Journal (Khotimah and Budiyono; 2019: 112-125).

However, a rather close study was written by Sesti Indah Pebriani in HARMONIA Journal Volume 13 Number 2 of 2013 entitled Bed Symbolic Meaning of the Bedaya Tunggal Soul Dance "(Pebriani; 2013: 120-131). This article specifically uses dance work in the form of the Bedaya Tunggal Jiwa dance as a symbolic form of Islamic values that makes artistic patterns.

\section{Research Methods}

For this reason this article will following an artistic method. This applied for artistic research related to dance creation and its forming as choreography text. The creation of art, specifically academic dance, must contain several creation methods. In this Srimpi Menak Lare dance, several methodological steps will be included by fulfilling the standards of the creation process academically. Basically, as in Guntur's statement, the creation of art is included in an artistic research field which contains creation by research (Guntur, 2014). Based on the statement above, the first artistic research performed was observation and literature study. The observation and literature process steps were done simultaneously because the dramatical source brought by the Srimpi Menak Lare dance is based on a play. The observation process was done differently from the typical research methods. As an artistic research method, the literature function was placed as a confirmation basis that makes up the 
dramatical structural element of the dance. In addition, the language used by children in their daily life is observed to inspire the production of its dance steps.

The second steps are interpretation and experimentation. This step is also performed simultaneously, because the results of the interpretation of the previous step was processed along with its interpretation. This means that the experimentation step is based on the interpretation pattern that functions as an inspiration of the work. In the experimentation step, new movements that considers the distinct bodies of child performers will be tested.

The third step is the formation. The forming method is an application of aesthetical and molding patterns. This is the last step of the experiment when the interpretation patterns are developed into technical, aesthetical and molding patterns. The result of this molding becomes the first step or prototype of the creation of the Srimpi Menak Lare dance. The last step is the performance. This step is a qualification test in front of the public. The acceptance of the Srimpi Menak Lare dance depends on its performance in the middle of the public. One of the tests that the Srimpi Menak Lare underwent was in the World Dance Day of 2018 in Gedung Teater Kecil ISI Surakarta on April 29th.

\section{Result and Discussion}

The study of the artistic creation of the Srimpi Menak Lare dance was not spontaneous. The transformation tradition in the molding of Srimpi was done before. The opening study of the Serat Menak's transformation into the Srimpi dance has been done (Pramutomo, 2010). The main study refers to an old literature called Serat Kondha Bedhaya Srimpi. This source mentions two preceeding Srimpi variations which are the Srimpi Pandhelori and Srimpi Muncar.

The main idea behind the creation of Srimpi Pandhelori also depicts the Serat Mena's dramatical source by taking its main characters, Dewi Sudarawerti and Dewi Sirtupilaheli. Meanwhile, the Srimpi Muncar bases its dramatical source on the strife between Dewi Kelaswara and Dewi Adaninggar (2009; 43).

From the data above, it can be seen that the dramatical source material of Serat Menak was an important inspiration during the rule of Sultan Hamengku Buwana VI. Both genres was created during the time of Sultan Hamengku Buwana VI (1855-1877). From a literature point of view, the text description of Serat Menak Lare by Yosodipuro I was publicized by CF in 1854. Then, it was published through Balai Pustaka by the efforts of R. Pandji Djaja Soebrata into 24 parts and 40 episodes on 1941. This publication is then spread widely and become known by the public (Soebardi, 1975). In this source material, the Serat Menak Lare tells a second part that depicts Wong Agung Menak (Amir Ambyah) as a young prodigy in warfare who bravely defeated knights and kings from other countries.

The form of dramatic material transformation that becomes the tale of Serat Menak Lare was adopted as the choreography flow of the Srimpi Menak Lare dance. The form of text in literature uses a chronological pattern. This is a typical method in creating a flow in the dramatical pattern, unlike the method used in a choreographic pattern. From a literature point of view, it is known that Wong Agung Menak was gifted in warfare since his childhood to his teenage years. The child psychological atmosphere was shortened when his prowess in warfare was not given the spiritual structure of a child's world, even though the interesting atmosphere was shown when the children's world was created through a dramatical narration in a choreographic form.

Hal ini menyebabkan daya tarik untuk This makes the allure to detect the main character's logical construction instantaneous. A transformative study about the characterization in Serat Menak was done by Istanti in Warna Lokal Text Amir Hamzah dalam Serat Menak, 2016. This piece depicts the name change of the main character from Arabic to Javanese, when The tale of Amir Hamzah was written into Serat Menak literature. This is proven in the change in phonemes and the addition of new words in the article. That is why the list of main characters in The tale of Amir Hamzah was localized by Javanese writers such as Yosodipuro I. Adanigr becomes Adaninggar, Mahira Negara becomes Muninggar, Bahti Jamal becomes Bekti Jamal, Bahtik becomes Bestak, Kuraisy Peri becomes Kuraisin, and Muqbal Khalib becomes Maktal (Istatni, 20160). The form of transformation in literature is different 
than the study of dance or drama. This is because the narrative text in dance is very short and it is shown differently than literature. Dance studies tend to use a choreographic flow.

When the literature text of Serat Menak Lare by Yosodipuro I was put into the choreographic flow of Serat Kondha Wayang Golek Menak, the creation of its dramatical atmosphere becomes even more creative, including the psychological atmosphere of its characters. The psychological atmosphere of childhood that is normally reduced during the choreographical flow could show the creation of art. The results of the observation of Serat Menak Lare's main character's psychology can be compared to the psychology from different forms of art.

The following table 1 contains the transformation of characterizations in a play based on the famous Serat Menak (R.M.Soedarsono 1989.)

Table 1 List of Character Comparison

\begin{tabular}{|c|c|}
\hline Wayang Menak Characters & Wayang Orang Characters \\
\hline Bekti Jamal & Abiyasa \\
\hline Alas Wajir & Sengkuni \\
\hline Betal Jemur & Abiyasa \\
\hline Raja Nursewan & Suyudana \\
\hline Patih Bestak & Durna \\
\hline Umarmaya & Bathara Narada \\
\hline Amir Ambyah & Arjuna \\
\hline Harya Maktal & Narayana \\
\hline Tamtanus & Harya Setyaki \\
\hline Lamdahur & Werkudara \\
\hline Umarmadi & Burisrawa \\
\hline Raja Jobin & Suteja \\
\hline Raja Bahman & Boma (Gusen) \\
\hline Raja Kistaham & Bogadenta \\
\hline Maryunani & Irawan \\
\hline Retna Muninggar & Sembadra \\
\hline Jarah Banun & Setyawati \\
\hline Sudarawerti & Srikandi \\
\hline Sirtupelaheli & Larasati \\
\hline Kelaswara & Srikandi \\
\hline Adaninggar & Banowati \\
\hline Kuraisin & Srikandi \\
\hline Ismayawati & Srikandi \\
\hline Iman Suwangsa & Angkawijaya \\
\hline Pirngadi & Sumitra \\
\hline Atas Aji & Parikesit \\
\hline Kalaranu & Bambang Sembotho \\
\hline Marikangen & Sarpakenaka \\
\hline Jayusman & Irawan \\
\hline Ruslan & Wilugangga \\
\hline Raja Jenggi & Rahwana \\
\hline Patuh Jedhi & Indrajit \\
\hline
\end{tabular}




\section{The Flow in Srimpi Dance}

The creation of Srimpi dance by using Serat Menak as a dramatic source can be seen in Srimpi Pandhelori and Srimpi Muncar during the era of Sultan Hamengku Buwana VI (1855 - 1877). During the era of Sultan Hamengku Buwana VII, both dances were a study material in the Krida Beksa Wirama dance school (KBW) led by Prince Suryodiningrat and Prince Tejakusuma. Through both princes and with the permission of the Sultan, a short version of Srimpi Pandhelori and Srimpi Muncar was developed in KBW.

Srimpi Pandhelori tells the tale of the strife between two warrior-princesses called Sudarawerti and Sirtupilaheli. The inspiration of the two character comes from Serat Menak Kanjun. The dramatical structure of Serat Menak Kanjun was transformed into the choreographic flow of Srimpi Pandhelori. Sudarawerti, the sister of king Kanjun sympathized with Wong Agung Menak Jayengrana who was tortured in the king's prison. Meanwhile, Sirtupilaheli or Rabingu, a princess of the Karsinah nation had a premonition to help Jayengrana which in her dream was prophesized to be her future husband.

The two warrior-princesses met in a rescue mission. Sudarawerti has fallen for Jayengrana because of a deep sympathy, while Sirtupilahei chased her dream and wanted to see if the prophecy was true by meeting the tortured Jayengrana. In the literature, both princesses met before knowing the other's motive and clashed. Both were tied in strength. It is told that Sudarawerti rides a garuda she received from her father called Garudayaksa. Sirtupilaheli also rides a garuda called Saomahi. During their battle, the two princesses asked each other's intentions and came to a truce to save Jayengrana.

This dramatical flow was choreographically transformed in a Srimpi dance pattern. Traditionally, the Srimpi was danced by four female dancers in a three-part pattern, as in table 2.

Table 2 The Structure of Presentation

\begin{tabular}{lll}
\hline First Part & \multicolumn{1}{c}{ Second Part } & \multicolumn{1}{c}{ Third Part } \\
\hline Kapang-kapang forward & Main Beksan. & Kapang-kapang backward \\
\hline $\begin{array}{l}\text { Four dancers move } \\
\text { forward with the same } \\
\text { pattern. }\end{array}$ & $\begin{array}{l}\text { Four dancers perform the } \\
\text { beksan with a pattern } \\
\text { movement. Main Beksan and } \\
\text { sub part in movement }\end{array}$ & $\begin{array}{l}\text { Four dancers move backwards } \\
\text { with the same pattern. }\end{array}$ \\
& sentences. & \\
\hline Goalpost pattern left & Goalpost pattern middle & Goalpost pattern right \\
\hline $\begin{array}{l}\text { Musical pattern of early } \\
\text { dance }\end{array}$ & $\begin{array}{l}\text { Musical pattern of main } \\
\text { dance of Pandhelori }\end{array}$ & Musical pattern of ending dance \\
\hline
\end{tabular}

The choreographic flow in the Srimpi dance will be seen in the second part, in the main beksan. This is because said part contains the source, beginning, peak, and end of the conflict. The source of the conflict can be seen from the choreographic pattern of the dance forming a certain pattern in the floor. The start of the conflict is shown by a change in the choreographic flow through a change in the movement and the pattern in the floor. The peak of the conflict is traditionally shown by a war pattern. The choreographic pattern synchronizes with the dramatic flow of the text where both characters are depicted in combat. The end of the conflict is shown by the floor pattern returning to its initial pattern. The four dancers perform kicat to the left and right as a transition that shows the end of the conflict before following it up with a ngayang pose and ending in a jengkeng pose. In Srimpi Pandhelori, the source of the conflict has been introduced by the narrator's dialogue in the beginning of the performance.

Another example of flow can be seen in Srimpi Muncar. The Srimpi Muncar dance tells the tale of two different warrior-princesses, Kelaswara and Adaninggar. The inspiration of these characters came from Serat Menak Cina. The dramatical structure of Menak Cina literature was transformed into Srimpi Muncar's choreographic flow. The tale tells of Adaninggar, the daughter of Hong Tete from Tartar who fell in love with Wong Agung Menak Jayengrana. The princess' decision to see Jayengrana was not complemented by the king's decision, as the king as matched her with Prince Nursewan. Meanwhile, 
Jayengrana has chosen to marry the daughter of king Kelan, named Kelaswara. Jayengrana respects Adaninggar as an in-law, because she will be matched to king Nursewan. This unrequited love broke Adaninggar's heart. One day, Adaninggar saw Kelaswara's intimacy with Jayengrana, so she dragged Kelaswara out of her house and challenged her to a fight. Both princesses fought each other until Kelaswara pierced Adaninggar with her enchanted arrow.

Sastra Menak Cina's text description becomes a tragedy that ends with Adaninggar's death. The dramatic flow of this tale was transformed into a choreographic flow but without the tragic ending. The choreographic flow was a choice made by the choreographer's imagination that did not match the literature's flow. Instead, the choreographic flow shows the princesses' skill and awe-inspiring might. This transformation is a distinct flow that shows the character's unique weapons, the enchanted arrow and magic sash that inspired the Srimpi Muncar dance. This dramatical flow has been transformed into the Srimpi pattern.

Traditionally, this Srimpi dance is also performed by four female dancers in a three-part pattern, as in table 3.

Table 3 The Structure of Presentation II

\begin{tabular}{|l|l|l|}
\hline First Part & Second Part & Third Part \\
\hline Kapang-kapang forward & Main Beksan. & Kapang-kapang backward \\
\hline $\begin{array}{l}\text { Four dancers move forward } \\
\text { with the same pattern. }\end{array}$ & $\begin{array}{l}\text { Four dancers perform the beksan } \\
\text { with a pattern movement. Main } \\
\text { Beksan and sub part in movement } \\
\text { sentences. }\end{array}$ & $\begin{array}{l}\text { Four dancers move } \\
\text { backwards with the same } \\
\text { pattern. }\end{array}$ \\
\hline Goalpost pattern left & Goalpost pattern middle & Goalpost pattern right \\
\hline $\begin{array}{l}\text { Musical pattern of early } \\
\text { dance }\end{array}$ & $\begin{array}{l}\text { Musical pattern of main dance } \\
\text { Pandhelori }\end{array}$ & $\begin{array}{l}\text { Musical pattern of ending } \\
\text { dance }\end{array}$ \\
\hline
\end{tabular}

The choreographic flow in the Srimpi dance will be seen in the second part, in the main beksan. This is because said part contains the source, beginning, peak, and end of the conflict. The source of the conflict can be seen from the choreographic pattern of the dance forming a certain pattern in the floor. The start of the conflict is shown by a change in the choreographic flow through a change in the movement and the pattern in the floor. The peak of the conflict is traditionally shown by a war pattern. The choreographic pattern synchronizes with the dramatic flow of the text where both characters are depicted in combat. The end of the conflict is shown by the floor pattern returning to its initial pattern. The four dancers perform kicat to the left and right as a transition that shows the end of the conflict before following it up with a ngayang pose and ending in a jengkeng pose. In Srimpi Muncar, the source of the conflict has been introduced by the narrator's dialogue in the beginning of the performance.

The transformative pattern of the literature flow into a choreographic flow in the Srimpi dance shown above can be seen as the transformation of a tale into a dance. The transformation itself, according to Burhan Nurgiyantoro is a change in one thing, which in this case, is culture. The change in culture can happen when the culture itself emerges in a different condition or environment. This emergence itself is a form of transformation $(1998 ; 18)$. At the end of the transformation, the original and its copy cannot be known. The illustration that happens in the Serat Menak's territory has been shown in the flow and phonemic changes in the character names.

Things become different when the flow is used as an analogue to a choreographic flow. Conceptionally, the choreography itself according to Snyder is show in a three-step process: stimulation, transformation, and unity. This is typical in the forming of choreography. When implemented, unity is the end of the transformation where the shape can be seen. In the end the choreography concept is implemented from a stimulation process that contains the idea field until the unity step which contains the conceptual field. The word Choreography comes from the Greek choreo which means dance, and grapho which means note. Word-by-word, choreography means "dance that notes" in the next development the meaning of choreography becomes "work" or "sequence" or "creation of dance" (Soedarsono, 1978). The method of how the choreography is shown is a genre in of 
itself. In the Srimpi choreography shown above, traditionally the genre is given the meaning of "a dance performed by four female dancers" (Wardana, 1981). Both dances that were created during the time of Sultan Hamengku Buwana VI in Yogyakarta clearly takes the transformative pattern from the dramatic flow in Serat Menak's text. The Srimpi Pandhelori and Srimpi Muncar dances becomes even more established at the time of Sultan Hamengku Buwana VII (1877-1921).

When Sri Mangkunegara VII sent his daughter, Gusti Nurul, to learn in Krida Beksa Wirama (KBW Yogyakarta, the two dances became the main material of her curriculum. When Gusti Nurrul got married, with the permission of the Sultan the dance became a material in Pura Mangkunegaran Surakarta, where it underwent a new adaptation and incubation (Tyas, 2016).

\section{The Choreography of Srimpi Menak Lare as a Text}

Discussion regarding a conceptual creation of art almost always stem from a field of ideas. If the art form is dance, then the form is identical with choreography. This is rational when choreography itself has a conceptual field as a measure for aesthetic technical qualification. On that basis, the field of choreography concept refers to the meaning when the form of dance can be seen by observing its genre's typology. In other words, choreography can be seen as a text. If the genre is a group showing, then the shape is based from several elements of its formation. Through these elements, choreography can mean the flow of the choreography. Y. Sumandiyohadi sees the flow as a form of several choreographic elements (2007: 23-28). The flow of choreography as a form can be detailed thusly: this following Tabel 4 explain the forming of movement pattern.

Table 4 Dance Forming

\begin{tabular}{|c|c|c|}
\hline No. & Forming Element & Description \\
\hline 1. & Motion Shape & $\begin{array}{l}\text { Motion is structured based on the principle of shape, } \\
\text { because motion is the main medium }\end{array}$ \\
\hline 2. & Motion Technique & $\begin{array}{l}\text { Technique is the way used for the process of creating } \\
\text { motion }\end{array}$ \\
\hline 3. & Movement Style & $\begin{array}{l}\text { Movement style is the characteristic in the motion } \\
\text { technique and style }\end{array}$ \\
\hline 4. & Number of Dancers & $\begin{array}{l}\text { The number of dancers is a basis of whether a dance is a } \\
\text { solo, a duo, or a group dance }\end{array}$ \\
\hline 5. & $\begin{array}{l}\text { Gender and Body } \\
\text { Posture }\end{array}$ & $\begin{array}{l}\text { The dancer's gender and body posture defines the genre } \\
\text { definition and the performers of the dance. }\end{array}$ \\
\hline 6. & Spatial Structure & $\begin{array}{l}\text { Spatial structure is the method of placing motion in } \\
\text { certain floor patterns. }\end{array}$ \\
\hline 7. & Time Structure & $\begin{array}{l}\text { Time structure is the method of placing motion in a } \\
\text { certain tempo and the control of rhythm, including the } \\
\text { end of the dance. }\end{array}$ \\
\hline 8. & Dramatical Structure & $\begin{array}{l}\text { Dramatical structure is the flow of each element, } \\
\text { structured in multiple segments. }\end{array}$ \\
\hline 9. & Performance Technicals & $\begin{array}{l}\text { Technicals contains makeup and costumes, lighting, and } \\
\text { property. }\end{array}$ \\
\hline
\end{tabular}

According to Snyder's thinking, the comparative focus is in motion as a text. The important meaning of the text analogy is that the motions become a hidden language of the dance itself. This is contained in the explanation of unity. If implemented in detail, the choreographic flow becomes

A foundation to form the concept of choreography itself. This is caused by the forming field containing the methods to conceptualize each elements of the flow above.

In a dance, the dramatic flow is in the motion. The study of choreographic concept is an explorative study for research-based creation. This refers to Guntur's view in the research-based creation method which is seen as an artistic research. Methodologically, the artistic research is categorized into five 
models: practice-based research, practice-led research, art-based research, studio-based research, and reflection practice (2016 $2^{\text {nd }}$ edition; 16-28). Referring to the artistic research model, this article is a practice-led research. According to Smith and Dean, practice-led research sees art as a from of research and the creation of art as the birth of research knowledge which then can be documented, theorized, and generalized, even though individual contributors can use other terms (2009; 6). From this point of view, an art form itself is a form of research. Therefore, it contains new knowledge and can be transformed into other contexts.

In a different approach to view the creative process of a dance, Snyder uses the three-field term which are stimulation, transformation, and unity (Bandem, 1997). Snyder's view, when implemented as a practice-led research has the same goal as viewing art as a research. The transformative element is process field from before the art itself is created. In the unity step, every motion has a meaning because the motions contain forms that have been previously conceptualized. This has also been applied by Y. Sumandiyohadi, how the shape element of motion is a medium. The motions of Srimpi Menak Lare can be further specialized in its application into 1. Unity, 2. Variation, 3. Repetition and transition, and 4. Motion.

In Hadi's view, those four practical applications of motion form a base of motion as text (2007:25). An important principle from the motion or choreography is unity. The unification process of the motions is a series of motions structured based on selection of form. Usually, the selection process is done by distortion and smoothing. The two methods are a system applied in form selection. However, in traditional dance the smoothing process is the dominant method in the form selection process.

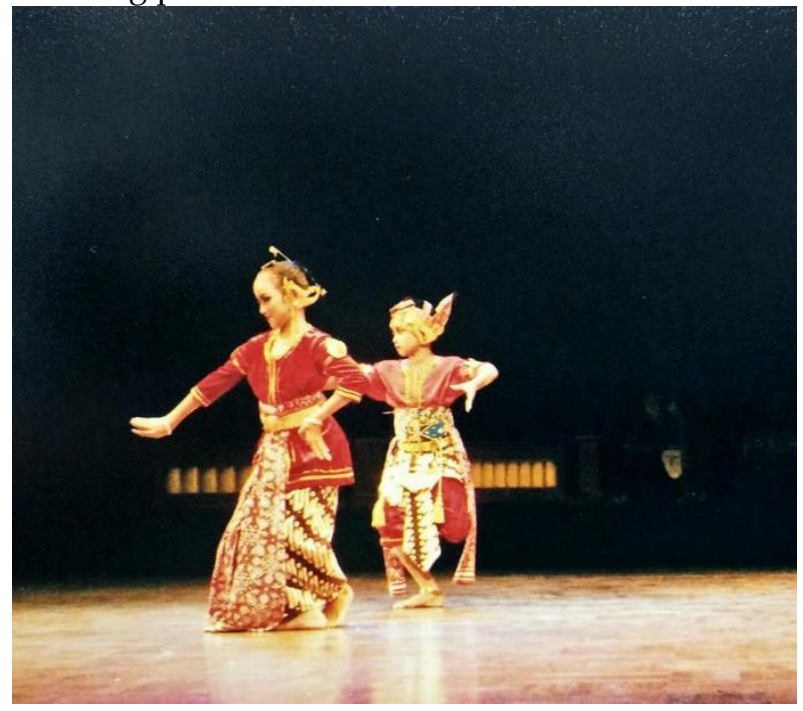

Figure 1 Arms position

The arms posistion in figure 1 depicting a movement pattern of children playing. It is a part of dance forming of movement with body's practice. The second practice in forming a motion form is the application of a variation of motion. This is also a common form in traditional dance. Variation patterns shows that each motion needs to be an improvement from the previous motion. Improvement in motion can be done by developing it without leaving its initial form.

In Srimpi Menak Lare, the pattern of motion development is found in the sembahan motion, as well as the forwards kapang-kapang motion in the beginning. The sembahan motion is done performed in the first sila position. The forwards kapang-kapang motion is done similar to tayungan in the male perfemrs. This variation of pattern is given a new variation by developing the tempo, which was adjusted with the music to the dance. Through the practical application of movement, a development of volume was abled. 


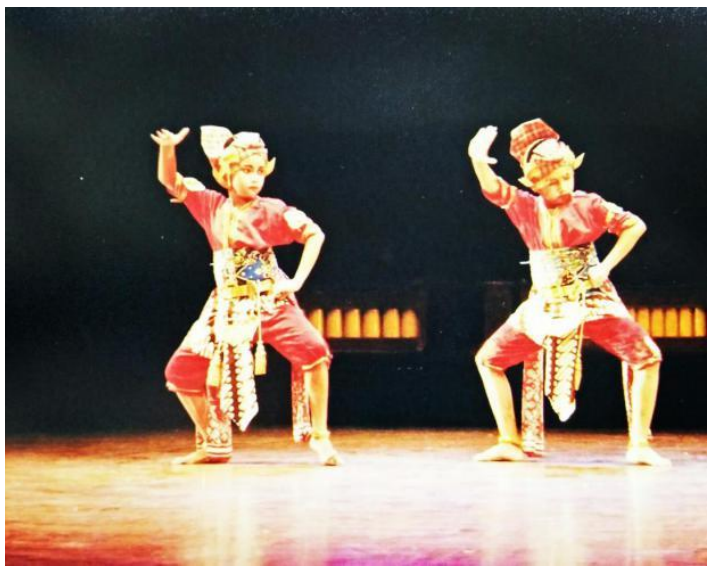

Figure 2 Trecet locomotion movement

The following practice in the creation of dance motions in Srimpi Menak Lare is by repetition and transition. The application of repetition is in a repeated movement pattern, repeated in a certain tempo and giving its audience a pleasant experience. This is important because by repeating certain motions, the audience connects the dance with a certain experience which makes the dance itself pleasant. In the Srimpi Menak lare, the repetition system can be seen in the trecet, kebyok, kebyak sampur, srisig, and oncang motions for the male performers.

Meanwhile, the application of transition is the locomotion of movement. This is done as the performers switch places. In the Srimpi Menak Lare, this can be seen in trecet, srisig, onclang, nggeblag, kengser, and besut.

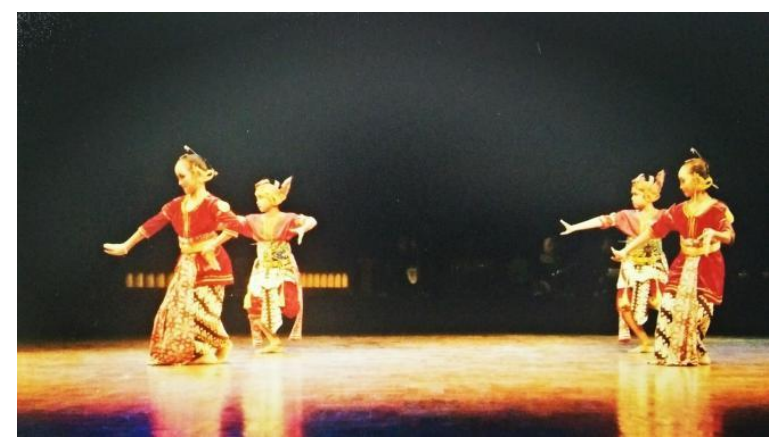

Figure 3 Penthangan position

The practice of application and motion forming is marked by the presence of motif. Penthangan motif is depicting the syncronize of both female and male dancers as in figure 3. It can be explained by simetrical motion. The process of movement works that produces motif is a form of transformation with a certain meaning. As a practical application in motion forming, the visual motif is a chain of motion performed back-to-back in a period of time. Therefore, when movement is created, it also contains a sense of motion or kinesthetic aspect. Like the figue below which is depicting srisig motif. It has similiar motion showed by both male and female dancers. It also means a pattern of movement contains the communication of choreography. 


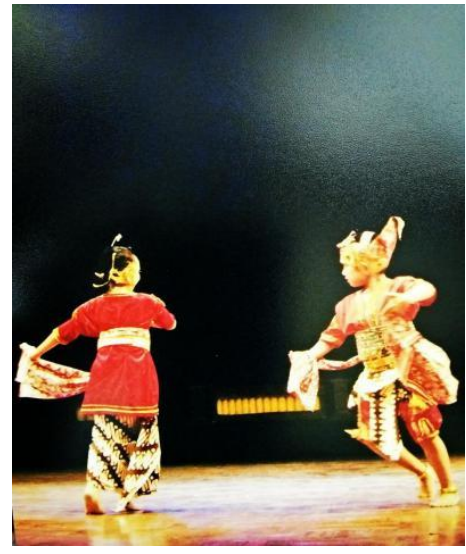

Figure 4 Srisig locomotion movement

Through this study, it can be seen that motion is choreography itself. Conceptually, choreography is a form of movement in a systematic and methodical structure. In a more concrete description, choreography is a construct of every motion in the form of dance. Analytically, the concept of choreography is based on the connected pattern in the form of dance. In the end, construct as a form is the text of dance itself.

This means that if the form of motion is treated as a choreographic text, then the form of motion is inherent with the technique and motion itself. This assumption becomes the base to see the transformational aspects in Snyder's view where the end of the transformation contains motif. In this discussion, the movement forms used in Srimpi Menak Lare dance is divided into two types: Main motion and connecting motion. Main motion is the base motion that shows the character or theme of the dance. Connecting motion is a motion used to connect one vocabulary with another. The following table 5 is an example of a motion in Srimpi Menak lare.

Table 5 Relation Dancing Body and Motif

\begin{tabular}{|c|c|c|c|}
\hline Part & Main movement & $\begin{array}{c}\text { Connective } \\
\text { motion }\end{array}$ & Details \\
\hline \multirow[t]{8}{*}{3} & Ngembat & & \\
\hline & Ngenceng seblak sampur & & \\
\hline & Kebyok sampur & & \\
\hline & Lerekan & & \\
\hline & Kebyok kebyak sampur & & \\
\hline & Lampah miring kebyok kebyak sampur & Onclang & Motif 1 \\
\hline & Trecet kebyok kebyak sampur & & \\
\hline & Penthangan hoyog & & \\
\hline
\end{tabular}

In the technical level, a technical connection between the concept of the dancers' body will be shown if the dancer's body segments are divided into four parts, then the parts can be seen as the head, the arms, the torso, and the legs. The entirety of the segmentation of the performers' bodies is a representation of the performed technique. In the process of dance creation, this level shows a choreographer that has considered the shape of motion in the base proportion balance in the performer's body segments. If structured into a chart, the technical qualification of the dancers can be seen thusly in figure 5: 


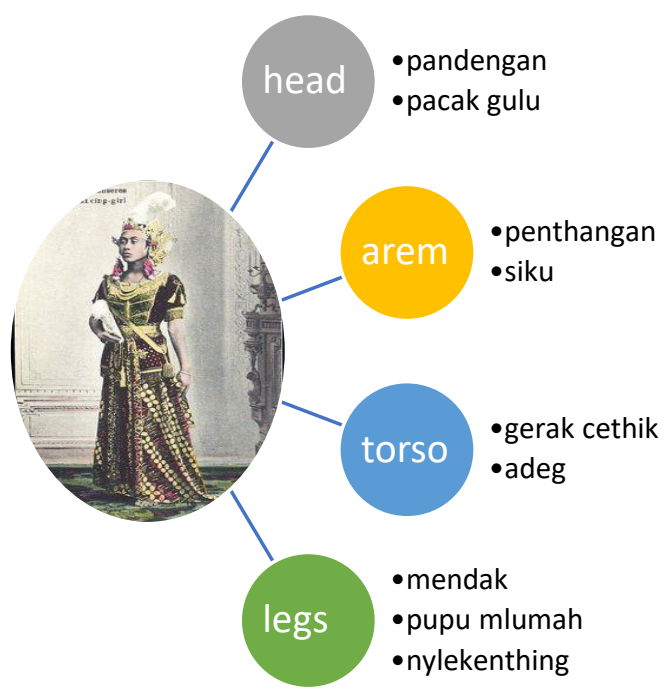

Figure 5 Elements of Dancing Bodies

In etymological terms, naming of the performers' body segments uses traditional Javanese terms. This is because in the creation process of Srimpi Menak Lare, the used base is in the Javanese tradition, especially in the Surakarta style. The four body segments of the dancers need to be a realization when used as an application of the conceptual creation of the choreography itself. This understanding is in line with a choreographic flow which will later form in visualizing the creation. For this reason, the study of body segments is important to understand the choreography of Srimpi Menak Lare.

Pandengan, which is often translated into view, is more than just the field of view of a performer to see the situation around them. Someone's view in dance must reflect the character they play. As a motion concept, pandengan contains the soul of the dance. In Yogyakarta's tradition, pandengan has several levels. In the first level, pandengan will form polatan which comes from the word 'ulat' (emotion). On the next level, polatan will form pasemon (semu). Dance expert Prince Suryobrongto states that pasemon is a projection that expresses the soul (Wibowo, 1981). This opinion strengthens the argument of the conceptional side of choreographic flow in the head segment.

In Srimpi Menak Lare, the pandegan's direction of its performers follow a pattern that is different between the girls' variation and the boys' alus vatiation. The girls' variation is timid, while the boys' variation is dynamic and whimsical by considering these variations, the view of the performers must contain their childish innocent. The 'ulat' of its young performers further reflects an innocent view.

The same situation is shown during the pacak gulu or neck movement, where the performers will express the same spiritual situation. In a technical qualification, neck movement is a difficult step for young dancers. Usually, young dancers will move the base of the neck or the head. Conceptionally, the movement in the base of the neck is the start of pacak gulu. This is then traditionally called jiling. At the same level, body language or torso movement for performers are mandatory.

The arm segment also sets the choreography style shown through the penthangan and elbow movement. The penthangan term traditionally covers the size or proportion connected to the volume of space made by the arms. If a normal size is applied horizontally, the size can be shown in the alus and gagah dance variation of the boys. For the girls, traditionally the motion will tend to point a little downwards. This is still used in traditional Javanese choreography. The same goes in the elbows. Traditional elbow variations can resemble certain angles if the arm segments are divided into the upper and lower arm.

In the alus boys' variation and girls' variation of the dance, the elbows will place the forearm in a low level or at most perpendicular to the shoulders but never over the angle of the upper arm.

In addition, choreography is dependant on the torso. This body segment will show where the dancers will face and its spiritual state that they represent. In other words, a dancer must not only be 
seen from the front, but also from their other sides. Therefor, a performer must perform the adeg stance well. The torso's stance is considered right when the adeg or straight form on the spine does not show tense shoulders. Technically, the choreographic flow does not demand the shoulders be slack. The key to aesthetical qualification is in the correct placement of spinal proportion.

The basic sequence of body movement in the torso also covers the cethic movement flow. Cethik or the base of the thigh tend to function as the support for the torso. Therefor, this segment is covered in the torso. The cethik movement has a crucial function for the balance of the dancer. The cethik movement is the base of every movement of the body when it is taken left or right. For example, in the hoyogan motion. Therefor, the application of cethic must be done right.

The immediate implication of performing the correct movement is indicated from the position of the dancer's thigh in the open state or pupu mlumah. In the end, the function of the balance will form a hoyogan pattern that comes from the base of the thigh and the mendak pattern that also comes from the base of the thigh. The mendak is a crouching position from the knees that is supported from the base of the thigh. When done right, the motion will strengthen the stance of the torso which is also supported by the base of the thigh. In choreography terms, the intensity of the dancer's body is affected by the mendak stability. A good mendak motion will form a proportional dance space, which shows the quality and the body intensity of the performer.

The technical qualification pattern of the mendak and pupu mlumah motions become the choreograpic flow shown by the legs segment. This is because both of the motion flows above are the direct cause of when the motion flows come from the cethik. The last segment of the analytical study of choreography as a text is proven by the supporting segment in the base of the knee as the nylekenthing movement. This is when the toes are straight up with a certain tension that shows the strength of the feet. This functions to show the might of a measured balance factor. This motion will show a performer's strength on the dance floor.

In this situation, the image of the performer during the dance will show a virtual imagination to the theme they bring. This image is the aim of the dance when it is created in a certain ethnic and aesthetic qualification. On one side, this image becomes the main element of the creation of the dance form. On the other, the virtual imagination will be apparent as an element of choreography. This is because the dance theme from certain views is shown with an aesthetic flair, and the dance moves were constructed through visualized body segments.

\section{Conclusion}

The study of choreography refers to how a dance can be analysed by viewing its typology genre. If the genre is a group showing, then the form is based on several of its elements. Through these elements, choreography can be seen as the base of choreography flow. In the creation of Srimpi Menak Lare, the basis used came from Javanese tradition, especially the Surakarta style. Choreography as a concept is observed from the motions as the beginning of the bodily constructs of the performer. In this level, the body is divided into four segments: head, arms, torso, and legs. These four segments are the main element to build the choreography construct. This is needed for a body when used as an application of form creation or choreography itself.

This understanding is in line with the view of the choreography flow that forms in visualizations of art. This is why it is important to discuss body segmentations as the main part of Srimpi Menak Lare's choreography flow. The entirety of a performer's body segments is a representation of the execution of a motion's technique. In the forming process of a dance, a choreographer has considered the performer's body. If put in segments, the technical qualification of those four body parts is a bodily factor in the understanding of text of certain dance genres is choreography itself. 


\section{References}

Astarinny, D. A., \& Pramutomo, R. M. (2020). Islamic Values in Bedhaya Sri Nawa Kumala Dance of Guruh Sukarno Putra Creation. Jurnal Kepariwisataan: Destinasi, Hospitalitas Dan Perjalanan, 4(1), 1-10. https://doi.org/10.34013/jk.v4i1.37.

Bandem, I. M. (1997. ). Etnologi Tari Bali. Yogyakarta: Yayasan Kanisius.

Guntur. (2014). Metode Penelitian Artistik. Surakarta: ISI Press Solo.

I., R. Y. (1981). Serat Menak Lare. Jakarta: Departemen Pendidikan dan Kebudayaan.

Istanti, K. Z. (2016). Warna Lokal Teks Amisr Hamzah Dalam Serat Menak. KAWISTARA.

Istanti, K. Z. (2016.). Warna Lokal Teks Amisr Hamzah Dalam Serat Menak. KAWISTARA .

Khotimah, Etti Khusnul and Alief Budiyono "Reducing Stress Levels in the Purbalingga Street Art Community through Graffiti and Murals" Journal of ILMU DAWAH, IAIN Wali Songo, Volume 39 Number 2 of 2019

Moehson, Qomariah in the title 'Da'wah Humanists Through the Movement of the Congregation' in Journal of ILMU DAWAH, IAIN Wali Songo, Volume 39 Number 2 of 2019

Pebriani, Sesti Indah 'Symbolic Meaning of the Bedaya Tunggal Jiwa Dance, Journal of HARMONIA, Universitas Negeri Semarang Volume 13 Number 2 , 2013

Pramutomo., R. (2010.). Tari, Seremoni, dan Politik Kolonial. Solo: ISI Press.

R.M.Soedarsono. (1989.). Sri Sultan Hamengku Buwana IX: Pengembang dan Pembaharu Tari Gaya Yogyakarta. Yogyakarta: Provinsi Daerah Istimewa Yogyakarta.

Soebardi. (1975.). The Book of Cabolek. The Hague Martinus Nijhoff.

Soedarsono, R. (1978). Pengantar Pengentahuan Tari. Yogyakarta: Proyek ASTI.

Tyas, E. P. (2016). Peranan Otoritas Estetis Dalam Penciptaan Tari Golek Lambangsari di Pura Mangkunegaran. Surakarta: ISI Surakarta.

Wibowo, F. (1981). Mengenal Tari Klasik Gaya Yogyakarta. Yogyakarta: Dewan Kesenian DIY.

(C) 2020 by the authors. Submitted for possible open access publication under the terms and conditions of the Creative Commons Attribution 4.0 International (CC BY 4.0) license (https://creativecommons.org/licenses/by/4.0/). 